\title{
Antioxidant, Membrane Stabilizing and Cytotoxic Activities of Cissus adnata (Roxb.)
}

\author{
Ridwan Bin Rashid ${ }^{1}$, Farhan Nur Towsif ${ }^{2}$, Farhana Ahmed Bushra ${ }^{2}$ \\ and Faiza Tahia ${ }^{3}$
}

\author{
${ }^{1}$ Department of Microbiology, University of Dhaka, Dhaka-1000, Bangladesh. \\ ${ }^{2}$ Department of Pharmacy, State University of Bangladesh, Dhaka-1205, Bangladesh. \\ ${ }^{3}$ Phytochemical Research Laboratory, Department of Pharmaceutical Chemistry, Faculty of Pharmacy, \\ University of Dhaka, Dhaka-1000, Bangladesh.
}

Received: May 19, 2016; Accepted: June 10, 2016; Published (web): June 20, 2016

\begin{abstract}
The methanol extracts of whole plant of Cissus adnata (Roxb.) and their organic and aqueous soluble partitioning materials were evaluated for antioxidant, cytotoxic and membrane stabilizing properties. In the DPPH free radical scavenging assay, the aqueous extract of whole plant of C. adnata displayed the highest free radical scavenging activity with $\mathrm{IC}_{50}$ value of $4.17 \mu \mathrm{g} / \mathrm{ml}$, while the pet ether soluble fraction showed significant lethality to brine shrimps having $\mathrm{LC}_{50}$ value of $1.02 \mu \mathrm{g} / \mathrm{ml}$, as compared to the standard vincristine sulphate $\left(\mathrm{LC}_{50}\right.$ value of 0.44 $\mu \mathrm{g} / \mathrm{ml})$. In the evaluation for membrane stabilizing property, the pet ether soluble fraction of methanol extract of the whole plant inhibited $67.43 \%$ and $56.60 \%$ hypotonic solution- and heat-induced haemolysis of RBCs, respectively.
\end{abstract}

Key words: Cissus adnata, antioxidant, cytotoxic, DPPH

\section{INTRODUCTION}

Cissus adnata (Roxb.) (Bengali/ local name: Bhatia-lot, Alianga-lata) belongs to the family Vitaceae. It is a deciduous, slender climber that can grow up to 5-15 m long. The bark is often reddish in colour, flaky, pubescent when young, with multicellular hairs, uniseriate and unicellular, 2-armed and usually with unbranched tendritis. ${ }^{1}$ It grows in vine thicket, monsoon forest, beach forest, seasonal rain forests in South East Asia, and has been imported to Brazil and the southern United States. ${ }^{2}$

The root is diuretic, blood purifier and used for the treatment for cough. Applied externally, it is used as a poultice on cuts, fractures and maturation of boils. In Bangladesh, the plant is traditionally used for treatment of boils, bruises, epilepsy, fever, food

Correspondence to: Faiza Tahia

Tel.: +880-2-9661900, Extn. 8131;

E-mail: faiza.tahia@gmail.com

Dhaka Univ. J. Pharm. Sci. 15(1): 69-71, 2016 (June) poisoning, gastric tumors, jaundice, gout, hysteria, snake bites, urolithiasis, etc. ${ }^{3}$

It has also been used for bone fractures, weak bones (osteoporosis), scurvy, cancer, stomach upset, hemorrhoids, peptic ulcer disease (PUD), painful menstrual periods, asthma, malaria, and pain. ${ }^{4}$ Previous phytochemical investigations of C. adnata led to the isolation of triterpenoids and resveratrol dimer quadrangularin A. ${ }^{1}$ Phytochemical studies on methanol extract revealed the presence of $\alpha$ - and $\beta$ amyrins, $\beta$-sitosterol, ketosteroids, phenols, tannins, carotene and vitamin $C^{5}$

As part of our continuing investigation on medicinal plants of Bangladesh, ${ }^{6,7}$ the crude methanol extracts of whole plant of C. adnata as well as their organic and aqueous soluble fractions were studied for the antioxidant potential in terms of total phenolic content and free radical scavenging activity, as well as cytotoxic, and membrane stabilising properties for the first time and we, here in, report the results of our preliminary investigations. 


\section{MATERIALS AND METHODS}

Collection of plant materials and extraction. The whole plant of C. adnata was collected in April 2015. Voucher specimens (Accession no: 40702) for the plant have been maintained in Bangladesh National Herbarium, Dhaka, Bangladesh for future reference.

The collected plant material was cleaned, sun dried and pulverized. The powdered plant material $(500 \mathrm{~g})$ was soaked in 2.0 liters of methanol at room temperature for 7 days. The extract was filtered through a fresh cotton bed and finally with Whatman number 1 filter paper. The filtrate was concentrated with a rotary evaporator at reduced temperature and pressure. An aliquot $(5 \mathrm{~g})$ of the concentrated methanol extract was fractionated by the modified Kupchan partitioning protocol $^{8}$ and the resultant partitionates were evaporated to dryness to yield petether (PESF: $0.65 \mathrm{~g}$ ), carbon tetrachloride (CTCSF: $0.55 \mathrm{~g}$ ), chloroform (CSF: $0.40 \mathrm{~g}$ ) and aqueous (AQSF: $2.50 \mathrm{~g}$ ) soluble materials. The residues were then stored in a refrigerator until further use.

Total phenolic content. The total phenolic content of the extractives was determined with FolinCiocalteau reagent by using the method developed by Harbertson and Spayd. ${ }^{9}$

$D P P H$ free radical scavenging assay. Following the method of Brand-Williams et al. ${ }^{10}$, the antioxidant activity of the test samples was assessed by evaluating the scavenging activities of the stable 1,1diphenyl-2-picrylhydrazyl (DPPH) free radical by using synthetic antioxidants, butylated hydroxytoluene (BHT) and ascorbic acid as reference standards.

Brine shrimp lethality bioassay/cytotoxicity assay. This technique was applied for the determination of general toxic properties of the dimethylsulfoxide (DMSO) solution of the extractives against Artemia salina in a single day assay by using vincristine sulphate as positive control. ${ }^{11}$

Membrane stabilizing activity. The membrane stabilizing activity of the extractives was evaluated by the inhibition of heat- and hypotonic solutioninduced haemolysis of human erythrocytes following the method developed previously. ${ }^{12}$
Statistical analysis. For all bioassays, three replicates of each sample were used for statistical analysis and the values are reported as mean $\pm \mathrm{SD}$.

\section{RESULTS AND DISCUSSION}

The crude methanol extract of whole plant of $C$. adnata as well as its Kupchan partitionates were evaluated for the total phenolic content, free radical scavenging, cytotoxic, and membrane stabilizing activities.

The total phenolic content of the extractives of whole plant of C. adnata was found to vary from $21.61 \pm 0.13$ to $88.70 \pm 0.45 \mathrm{mg}$ of $\mathrm{GAE} / \mathrm{g}$ of extractives, with the highest amount of phenolics $(88.70 \pm 0.45 \mathrm{mg}$ ) being observed in the aqueous soluble materials (Table 1).

In the DPPH free radical scavenging assay, the aqueous soluble fraction revealed maximum free radical scavenging activity having $\mathrm{IC}_{50}$ value of 4.17 $\pm 0.78 \mu \mathrm{g} / \mathrm{ml}$ while the standard ascorbic acid and BHT showed $\mathrm{IC}_{50}$ values of $3.06 \pm 0.32 \mu \mathrm{g} / \mathrm{ml}$ and $27.60 \pm 0.55 \mu \mathrm{g} / \mathrm{ml}$, respectively (Table 1 ).

In the brine shrimp lethality bioassay, the pet ether soluble partitionate of whole plant of $C$. adnata displayed the highest cytotoxic potential with $\mathrm{LC}_{50}$ value $1.02 \pm 0.08 \mu \mathrm{g} / \mathrm{ml}$ as compared to $0.43 \pm 0.03$ $\mu \mathrm{g} / \mathrm{ml}$ for vincristine sulphate. This suggested the presence of potent bioactive components in the above mentioned extractives (Table 1).

The membrane stabilizing activity of the extractives of C. adnata was also determined. They significantly protected the lysis of human erythrocyte membrane induced by both heat- and hypotonicsolution, as compared to the standard acetyl salicylic acid. In hypotonic solution-induced condition, the pet ether soluble fraction of C. adnata inhibited $67.43 \pm$ $0.44 \%$ haemolysis of RBCs as compared to $72.40 \pm$ $0.48 \%$ revealed by acetyl salicylic acid $(0.10 \mathrm{mg} / \mathrm{ml})$ (Table 1). On the other hand, in heat-induced condition, the pet ether soluble fraction inhibited 56.6 $\pm 0.21 \%$ haemolysis of RBCs as compared to 42.10 $\pm 0.22 \%$ showed by acetyl salicylic acid $(0.10$ $\mathrm{mg} / \mathrm{ml}$ ) (Table 1). 
Table 1. Total phenolic content, free radical scavenging, cytotoxic and membrane-stabilizing activities of $C$. adnata.

\begin{tabular}{|c|c|c|c|c|c|}
\hline \multirow[t]{2}{*}{ Sample/ Standard } & \multirow{2}{*}{$\begin{array}{c}\text { Total phenolic } \\
\text { content (mg of } \\
\text { GAE/gm of extract) }\end{array}$} & \multirow{2}{*}{$\begin{array}{l}\text { DPPH Free radical } \\
\text { scavenging activity } \\
\left(\mathrm{IC}_{50} \mu \mathrm{g} / \mathrm{ml}\right)\end{array}$} & \multirow{2}{*}{$\begin{array}{l}\text { Cytotoxicity } \\
\left(\mathrm{LC}_{50} \mu \mathrm{g} / \mathrm{ml}\right)\end{array}$} & \multicolumn{2}{|c|}{$\%$ inhibiton } \\
\hline & & & & $\begin{array}{l}\text { Hypotonic } \\
\text { solution- } \\
\text { induced }\end{array}$ & Heat-induced \\
\hline ME & $66.43 \pm 0.61$ & $9.58 \pm 0.43$ & $1.74 \pm 0.45$ & $21.75 \pm 0.66$ & $11.60 \pm 0.23$ \\
\hline PESF & $21.61 \pm 0.13$ & $64.07 \pm 0.23$ & $1.02 \pm 0.08$ & $67.43 \pm 0.44$ & $56.60 \pm 0.21$ \\
\hline CTCSF & $45.89 \pm 0.45$ & $38.18 \pm 0.76$ & $1.10 \pm 0.62$ & $32.81 \pm 0.84$ & $24.20 \pm 0.56$ \\
\hline CSF & $78.56 \pm 0.56$ & $4.35 \pm 0.65$ & $1.14 \pm 0.44$ & $15.03 \pm 0.67$ & $2.150 \pm 0.44$ \\
\hline AQSF & $88.70 \pm 0.45$ & $4.17 \pm 0.78$ & $1.74 \pm 0.59$ & $40.35 \pm 0.84$ & $34.60 \pm 0.32$ \\
\hline Acetyl salicylic acid & & & & $72.40 \pm 0.48$ & $42.10 \pm 0.22$ \\
\hline VS & - & - & $0.43 \pm 0.03$ & & \\
\hline BHT & - & $27.60 \pm 0.55$ & - & & \\
\hline Ascorbic acid & - & $3.06 \pm 0.32$ & - & & \\
\hline
\end{tabular}

$\mathrm{ME}=$ Methanolic crude extract; $\mathrm{PESF}=$ Pet-ether soluble fraction; $\mathrm{CTCSF}=$ Carbon tetrachloride soluble fraction; $\mathrm{CSF}=\mathrm{Chloroform}$ soluble fraction; $\mathrm{AQSF}=$ Aqueous soluble fraction; $\mathrm{BHT}=$ Butylated hydroxy toluene; $\mathrm{VS}=$ Vincristine sulfate

\section{CONCLUSION}

It is clearly evident from the above findings that C. adnata has significant phenolic content as well as free radical scavenging, cytotoxic and membrane stabilizing properties. The plant is traditionally used for inflammation, infection, gastric tumors, cancer etc. Our findings justify some of these folkloric uses of this plant. Thus, the plant is a promising candidate for further phyto-pharmacological investigation to isolate the active constituents.

\section{REFERENCES}

1. https://en.wikipedia.org/wiki/Cissus_quadrangularis (accessed on 24 April 2016)

2. Hnatiuk, R.J. 1990. Gensus of Australian vascular plants. Australian Flora and Fauna 11.

3. http://www.ebbd.info/cissus-adnata.html (accessed on 24 April 2016)

4. http://www.mpbd.info/plants/cissus-adnata.php (accessed on 24 April 2016)

5. Shah, U. 2011. Cissus quadrangularis: phyto-chemicals, traditional uses and pharmacological activities - a review. Int. J. Pharm. Pharm. Sci. 3, 41-44.
6. Tahia, F., Sikder, M.A., Haque, M.R., Shilpi, J.A., Awang, J., Mansur, M.M.A. and Rashid, M.A. 2015. Alkaloids, coumarin and cinnamic acid derivative from Murraya koenigii (Linn.) Spreng. Dhaka Uni. J. Pharm. Sci. 14, 29-33.

7. Tahia, F., Sikder, M. A., Sayeed, M.A. and Rashid, M.A. 2014. Bioactivities of Murraya koenigii (Linn.) and Adina cordifolia (Roxb.). Bangladesh Pharm. J. 18, 25-29.

8. Vanwagenen, B.C., Larsen, R., Cardellina, J.H., Randazzo, D., Lidert, Z.C. and Swithenbank, C. 1993. Ulosantoin, a potent insecticide from the sponge Ulosa ruetzleri. J. Org. Chem. 58, 335-337.

9. Harbertson, J. and Spayd, S. 2006. Measuring phenolics in the winery. Am. J. Enol. Vitic. 57, 280-288.

10. Brand-Williams, W., Cuvelier, M.E. and Berset, C. 1995. Use of free radical method to evaluate antioxidant activity. Lebensm. Wiss. Technol. 28, 25-30.

11. Meyer, B.N., Ferringni, N.R., Puam, J.E., Lacobsen, L.B., Nichols, D.E. and McLaughlin, J.L. 1982. Brine shrimp: a convenient general bioassay for active constituents. Planta Med. 45, 31-32.

12. Omale, J. and Okafor, P.N. 2008. Comparative antioxidant capacity, membrane stabilization, polyphenols composition and cytotoxicity of the leaf and stem of Cissus multistriata. Afr. J. Biotechnol. 7, 3129-3133. 